\title{
Salinity Tolerance and Recovery Attributes of Warm-season Turfgrass Cultivars
}

\author{
Manuel Chavarria \\ Prairie Turfgrass Research Centre, Olds College, Calgary, Alberta, Canada
}

Benjamin Wherley ${ }^{2}$ and James Thomas ${ }^{1}$

Texas A\&M AgriLife Research, College Station, TX 77843

Ambika Chandra

Texas A\&M AgriLife Research, Dallas, TX 75252

\section{Paul Raymer}

Department of Crop and Soil Sciences, University of Georgia, Griffin, GA 30223

Additional index words. salt stress, irrigation, bermudagrass, Cynodon, zoysiagrass, Zoysia, st. augustinegrass, Stenotaphrum secundatum, seashore paspalum, Paspalum vaginatum, electrical conductivity, $\mathrm{EC}_{50}$

\begin{abstract}
As population growth places greater pressures on potable water supplies, nonpotable recycled irrigation water is becoming widely used on turfgrass areas including golf courses, sports fields, parks, and lawns. Nonpotable recycled waters often have elevated salinity levels, and therefore turfgrasses must, increasingly, have good salinity tolerance to persist in these environments. This greenhouse study evaluated 10 commonly used cultivars representing warm-season turfgrass species of bermudagrass (Cynodon spp.), zoysiagrass (Zoysia spp.), st. augustinegrass [Stenotaphrum secundatum (Walt.) Kuntze], and seashore paspalum (Paspalum vaginatum Swartz) for their comparative salinity tolerance at electrical conductivity (EC) levels of 2.5 (control), 15 , 30 , and $45 \mathrm{dS} \cdot \mathrm{m}^{-1}$. Salinity treatments were imposed on the grasses for 10 weeks via subirrigation, followed by a 4-week freshwater recovery period. Attributes, including turf quality, the normalized difference vegetation index (NDVI), canopy firing, and shoot biomass reductions were evaluated before and after salinity stress, as well as after the 4week freshwater recovery period. Results showed considerable differences in salinity tolerance among the cultivars and species used, with the greatest tolerance to elevated salinity noted within seashore paspalum cultivars and Celebration ${ }^{\circledR}$ bermudagrass. In comparison with growth in $2.5-\mathrm{dS} \cdot \mathrm{m}^{-1}$ control conditions, increased shoot growth and turf quality were noted for many bermudagrass and seashore paspalum cultivars at $15 \mathrm{dS} \cdot \mathrm{m}^{-1}$. However, st. augustinegrass and some zoysiagrass cultivars responded to elevated salinity with decreased growth and turf quality. No cultivars that had been exposed to 30- or $45-\mathrm{dS} \cdot \mathrm{m}^{-1}$ salinity recovered to acceptable levels, although bermudagrass and seashore paspalum recovered to acceptable levels after exposure to $15-\mathrm{dS} \cdot \mathrm{m}^{-1}$ salinity. More severe salinity stress was noted during year 2, which coincided with greater greenhouse temperatures relative to year 1 .
\end{abstract}

Water quantity and quality are major issues of concern around the world, particularly in arid and semiarid areas where water shortages have resulted from rapid urbanization, agriculture, and/or industry (Huang et al., 2014). Elevated salinity is often an agronomic problem associated with use of recycled water sources (Harivandi, 2008),

\footnotetext{
Received for publication 13 Feb. 2019. Accepted for publication 18 Apr. 2019.

This work was funded through support from the U.S. Department of Agriculture, National Institute for Food and Agriculture Specialty Crops Research Initiative under award no. 2010-51181-21064.

${ }^{1}$ Retired.

${ }^{2}$ Corresponding author. E-mail: b-wherley@tamu. edu.
}

overuse of aquifers and/or saltwater intrusion (Carrow et al., 2001a; Moreaux and Reynaud, 2001), or may result from capillary rise of salts into the root zone (Armstrong et al., 1996). Salts can negatively affect plant development by damaging physiological processes through ion toxicity, ion imbalances, osmotic stress, or reduced soil permeability (Carrow et al., 2001a)

In the southern United States, landscape water conservation programs have been developed by municipalities and water purveyors to help alleviate pressures on potable water supplies. As a result, recycled wastewater is rapidly becoming a primary source of irrigation for turfgrass acreages including golf courses, parks, and athletic fields (Devitt et al., 2004). According to the Golf Course Superintendents Association of America's
Environmental Institute for Golf Survey (Golf Course Superintendents Association of America, 2015), recycled water has become the primary irrigation source used by golf courses in both the southeastern and southwestern regions $(35 \%$ of facilities in each region) of the United States. Increased regulations on direct discharge of effluent have also resulted in a growing number of communities throughout the country providing recycled wastewater to residences and commercial properties for use in landscape irrigation (Rojeski and Luster-Teasley, 2008).

Turfgrasses are generally well suited for recycled wastewater because they function as biological filters that can assimilate excess nutrients and, to some extent, salts from saline water (Hayes et al., 1990). Bermudagrass, seashore paspalum, zoysiagrass, and st. augustinegrass are four of the most widely used turf species in tropical and subtropical regions (Uddin and Juraimi, 2013). However, there have been limited published studies focused on evaluating comparative salinity tolerance and recovery attributes among many of the currently used cultivars of these species. Such information is important both for proper species and cultivar selection, as well as for improving and developing superior warm-season turfgrasses through breeding efforts (Abraham et al., 2008). Therefore, the objectives of this research were to evaluate comparative salinity tolerance and recovery attributes after salinity stress among 10 commonly used warm-season turfgrass cultivars representing bermudagrass, zoysiagrass, st. augustinegrass, and seashore paspalum.

\section{Material and Methods}

Growing conditions and plant materials. This study was conducted in a greenhouse at Texas A\&M University, College Station, TX. from 1 May through 15 Aug. 2014 (year 1), with a repeat study conducted from 1 June through 15 Sept. 2015 (year 2). Ten warmseason turfgrass cultivars were used, representing bermudagrass species, zoysiagrass species, st. augustinegrass, and seashore paspalum. Cultivars included 'Tifway' interspecific hybrid bermudagrass (Cynodon dactylon $\times C$. transvaalensis Burt. Davy); 'Riley's Super Sport' (Celebration $\left.{ }^{\circledR}\right)$ bermudagrass (Cynodon dactylon); 'SS-500' (Empire $\left.^{(}\right)$and 'Palisades' japanese lawngrass (Zoysia japonica Steud.); Zeon Zoysia ${ }^{\circledR}$ manilagrass [Zoysia matrella (L.) Merr.]; 'Raleigh', 'Floratam', and 'SS-100' (Palmetto ${ }^{\circledR}$ ) st. augustinegrass [Stenotaphrum secundatum (Walt.) Kuntze]; and 'Sea Isle 1' and 'UGA 31' (SeaStar ${ }^{\circledR}$ ) seashore paspalum (Paspalum vaginatum Swartz).

Before study initiation, circular sod plugs (5-cm diameter $\times 5-\mathrm{cm}$ depth) of each entry were obtained from breeder source material, washed free of soil, and the roots trimmed to $5 \mathrm{~cm}$ before transplanting into $100-\mathrm{cm}^{2} \times$ 10.2-cm-deep pots containing U.S. Golf 
Association-specified sand (U.S. Golf Association, 2004). Particle size analysis of the sand indicated the following fractions were present: $<0.15 \mathrm{~mm}, 1.7 \% ; 0.15$ to $0.25 \mathrm{~mm}, 13.9 \%$; 0.25 to $0.50 \mathrm{~mm}, 55.2 \%$; 0.5 to $1.0 \mathrm{~mm}, 23.1 \%$; 1.0 to $2.0 \mathrm{~mm}, 4.7 \%$; and $>2.0 \mathrm{~mm}, 0.3 \%$. The sand had been amended with $10 \%$ sphagnum peatmoss (v/ $\mathrm{v}$ ), and was determined through laboratory testing to contain $0.7 \%$ organic matter by volume, with a total porosity of $39.6 \%$. The washed sod plugs were allowed to establish fully into pots for $150 \mathrm{~d}$ in the greenhouse before initiating salinity treatments. During establishment, grasses were irrigated daily with $0.6 \mathrm{~cm}$ municipal tap water and were provided liquid fertilization twice weekly using a 20-20-20 water soluble fertilizer (Peters 20-20-20; J.R. Peters, Inc., Allentown, PA) to supply $1.2 \mathrm{~g} \mathrm{~N} / \mathrm{m}^{2} /$ week. The fertilizer also contained $\mathrm{Mg}(0.05 \%)+\mathrm{B}$ $(0.0068 \%)+\mathrm{Cu}(0.0036 \%)+\mathrm{Fe}(0.05 \%)$ $+\mathrm{Mn}(0.025 \%)+$ Mo $(0.0009 \%)+\mathrm{Zn}$ $(0.0025 \%)$. During establishment and subsequent salinity acclimation, stress, and recovery periods, grasses were clipped weekly using scissors with clippings removed. Bermudagrass species, zoysiagrass species, and seashore paspalum cultivars were maintained at a $2.5-\mathrm{cm}$ height of cut whereas st. augustinegrass was maintained at 5 -cm height of cut.

Acclimation, salinity stress, and recovery periods. Replicate studies consisting of four salinity levels of 2.5 (control), 15, 30, and 45 $\mathrm{dS} \cdot \mathrm{m}^{-1}$ EC were supplied via subirrigation into $1-\mathrm{m} \times 1-\mathrm{m} \times 5$-cm-deep ebb and flow benches, similar to the method published by Raymer et al. (2005). The control treatment EC of $2.5 \mathrm{dS} \cdot \mathrm{m}^{-1}$ was the result, primarily, of the salinity generated by the soluble fertilizer used to maintain growth in each treatment and, to a lesser extent, the salinity of the municipal tap water used $\left(0.9 \mathrm{dS} \cdot \mathrm{m}^{-1}\right)$. Within each salinity level, the 10 cultivars were arranged in a completely randomized design with four replicates.

Before initiating the study, a 5-week salinity acclimation period was provided to achieve gradually the desired target salinity concentrations while reducing the potential for acute salinity stress, similar to that pub- lished by Raymer et al. (2005). The acclimation period in year 1 was initiated 1 May 2014, and in year 2 on 1 June 2015. During acclimation, potted grasses were placed into ebb and flow benches and subirrigated daily. Salinity treatments were prepared by mixing municipal tap water $\left(\mathrm{pH}, 8.1 ; \mathrm{EC}, 0.9 \mathrm{dS} \cdot \mathrm{m}^{-1}\right)$ with Instant Ocean Sea Salt (Instant Ocean Spectrum Brands, Blacksburg, VA) to achieve the desired EC treatment levels. Instant Ocean Peters Professional 13-2-13 + $\mathrm{Ca}(6 \%)+\mathrm{Mg}(3 \%)$ soluble fertilizer (ICL Fertilizers, Dublin, $\mathrm{OH}$ ) was used to produce an irrigation nutrient concentration of $300 \mathrm{ppm} \mathrm{NO}_{3}-\mathrm{N}$ within all salinity treatments. Nutrient solutions were supplemented weekly with $\mathrm{CaSO}_{4}$ and $\mathrm{MgSO}_{4}$ to maintain an additional $460 \mathrm{ppm} \mathrm{Ca}, 100 \mathrm{ppm} \mathrm{Mg}$, and $390 \mathrm{ppm} \mathrm{S}$, as recommended by Raymer et al. (2005). During the acclimation phase, the salinity levels of each treatment were gradually increased by $10 \mathrm{dS} \cdot \mathrm{m}^{-1} \cdot \mathrm{week}^{-1}$ until the final desired salinity concentrations of 15,30 , and $45 \mathrm{dS} \cdot \mathrm{m}^{-1}$ were reached. Salinity was increased incrementally in this way to reduce the potential for acute salinity stress. During subirrigation events, water was pumped (Universal Electric Co. TEEL 115 V; Mississauga, ON, Canada) from 189-L holding tanks to fill ebb and flow benches completely for a 5-minute period, allowing sand root zones within pots to become fully saturated. A float valve was positioned near the upper edge of each ebb and flow bench to prevent overflow and to stop pump operation when water reached the soil surface of pots. In this way, the aboveground portions of the potted turfgrasses were never exposed to the saline irrigation during irrigation events. After acclimation, the 5-week studies were initiated simultaneously.

During both the acclimation and salinity stress periods, water levels in treatment holding tanks were measured and supplemented twice weekly to replace water lost to evaporation. Pots were also overheadflushed with municipal tap water once weekly just before subirrigating to prevent accumulation of salts at the soil surface. After the 5-week salinity stress period, a 4-week freshwater recovery period was initiated in all treatments. During the recovery period, all

Table 1. Greenhouse environmental conditions during acclimation, salinity stress, and recovery periods for the Texas A\&M salinity experiments. Weather data were obtained using a WatchDog 2000 Weather Station mounted in the center of the experimental area.

\begin{tabular}{|c|c|c|c|c|c|}
\hline & \multirow{2}{*}{$\begin{array}{c}\text { Mean daily } \\
P A R\left(\mathrm{~W} \cdot \mathrm{m}^{-2}\right)\end{array}$} & \multirow{2}{*}{$\begin{array}{l}\text { Mean relative } \\
\text { humidity (\%) }\end{array}$} & \multicolumn{3}{|c|}{ Temperature $\left({ }^{\circ} \mathrm{C}\right)$} \\
\hline & & & High & Low & Mean \\
\hline \multicolumn{6}{|l|}{ Year 1 (2014) } \\
\hline Acclimation period ${ }^{\mathrm{z}}$ & 160 & 85 & 30.5 & 23.3 & 26.6 \\
\hline Salinity stress ${ }^{y}$ & 173 & 87 & 32.7 & 22.7 & 28.3 \\
\hline Recovery period $^{\mathrm{x}}$ & 148 & 87 & 35.0 & 24.4 & 28.3 \\
\hline \multicolumn{6}{|l|}{ Year $2(2015)$} \\
\hline Acclimation period ${ }^{\mathrm{z}}$ & 160 & 87 & 36.6 & 23.8 & 28.3 \\
\hline Salinity stress ${ }^{y}$ & 176 & 79 & 34.4 & 26.6 & 30.0 \\
\hline Recovery period $^{x}$ & 138 & 78 & 34.4 & 26.1 & 30.0 \\
\hline
\end{tabular}

${ }^{\mathrm{z}}$ The acclimation period was weeks 1 to 5 .

${ }^{\mathrm{y}}$ The salinity stress period was weeks 6 to 10 .

${ }^{\mathrm{x}}$ The recovery period was weeks 11 to 14 .

$P A R=$ photosynthetically active radiation $(400-700 \mathrm{~nm})$. treatments received $1.5 \mathrm{~cm}$ overhead irrigation twice weekly using the municipal tap water $\left(\mathrm{EC}, 0.9 \mathrm{dS} \cdot \mathrm{m}^{-1}\right)$ to evaluate recovery under nonstressed conditions.

During acclimation and salinity stress periods, EC and nitrate concentrations of irrigation water holding tanks were monitored twice weekly. Salinity was measured using a portable EC meter (EC 110 Meter Field Scout; Spectrum Technologies, Inc., Aurora, IL) whereas nitrate concentrations were measured using a compact $\mathrm{NO}_{3}-\mathrm{N}$ ion meter (LAQUA Twin Nitrate Meter; Spectrum Technologies). When necessary, fertilizer was added to compensate for nutrient depletion from the system to maintain a target concentration of $300 \mathrm{ppm}$ $\mathrm{NO}_{3}-\mathrm{N}$ within each salinity treatment during the acclimation and salinity stress periods.

Environmental conditions. Environmental conditions in the greenhouse were monitored during the study period using a weather station (WatchDog 2000 Weather Station; Spectrum Technologies). Solar radiation, relative humidity, and temperature (daily high, low, and mean) were recorded and averaged for each phase of the study (acclimation, salinity stress, and recovery) during both years (Table 1).

Data collection. For evaluating turfgrass response to and recovery from salinity stress, turfgrass visual quality, canopy firing, NDVI, percent shoot biomass reduction, and final root biomass were measured during the study. Grasses were rated visually for turfgrass quality using a 0 - to 9-point scale, modified from Morris and Shearman (1998), where 0 is completely brown turf (worst quality), 6 is minimum acceptable, and 9 is ideal turf quality. Canopy firing was rated visually using a 0to 9-point scale, where 0 is no green tissue in the canopy and 9 is completely green canopy with no brown tissue present. Turfgrass quality and canopy firing measurements were taken both before and after salinity stress exposure (start of week 1 acclimation and end of week 10 salinity stress), as well as at the conclusion of the 4-week recovery period (week 14). Percent change in turf quality and firing resulting from salinity stress was measured by comparing the "post" (end of week 10) turf rates of each entry to its initial quality before salinity exposure.

Shoot growth rates within each treatment were also measured from weeks 1 through 10 by clipping grasses weekly to the optimu, recommended cutting heights (Duble, 1996) of $2.5 \mathrm{~cm}$ (bermudagrass, seashore paspalum, and zoysiagrass) and $5 \mathrm{~cm}$ (st. augustinegrass). Clippings for each entry were ovendried (VWR Gravity Convention Oven; VWR U.S.A., Atlanta, GA) for $72 \mathrm{~h}$ at $65{ }^{\circ} \mathrm{C}$ with dry weights measured using a digital scale (Denver Instrument P-403 Digital Balance; Denver Instrument, Bohemia, NY).

After acclimation and salinity stress exposure (week 10), clipping dry weights for each of the treatments were averaged over the 6 weeks of salinity stress to calculate percent 
reductions in shoot biomass occurring as a result of salinity stress. The following formula was used to determine percent biomass reduction:

Percent shoot biomass reduction

$$
=\left[1-\left(\frac{a}{b}\right)\right] \times 100,
$$

where $a$ is the clipping dry weight average over the 5-week salinity stress exposure period for a given cultivar and replicate within a given salinity treatment, and $b$ is the clipping dry weight average over the 5week salinity stress exposure period for the same cultivar and replicate within the control treatment

Before initiating the freshwater recovery period at week 11, turfgrasses were evaluated using NDVI (Field Scout TCM 500 NDVI, Turf Color Meter Spectrum; Spectrum Technologies) to determine relative differences in photosynthetic efficiency.

After the freshwater recovery period, roots were harvested from all pots, rinsed free of sand, and oven-dried for $72 \mathrm{~h}$ at $65^{\circ} \mathrm{C}$. Root dry weights as well as percent root biomass reduction were then determined for each treatment. The following formula was used to determine percent root biomass reduction:

Percent biomass reduction $=\left[1-\left(\frac{a}{b}\right)\right] \times 100$,

where $a$ is the final root dry weight for a given cultivar and replicate within a given salinity treatment, and $b$ is the final root dry weight for the same cultivar and replicate in the control treatment

At the conclusion of the experiment, data were subjected to analysis of variance using the general linear model univariate test procedure (SPSS version 21.0; IBM Corporation, Armonk, NY) to determine statistical significance of the results. Mean separation procedures were performed using Fisher's least significant difference at the $P \leq 0.05$ level.

\section{Results}

Environmental conditions. During the 2014 study (year 1), maximum daily temperatures during the three experimental phases (acclimation period, salinity stress, and recovery period) averaged $30.5,32.7$, and $35.0{ }^{\circ} \mathrm{C}$, respectively, whereas minimum temperatures averaged 23.3, 22.7, and $24.4{ }^{\circ} \mathrm{C}$, respectively (Table 1). During the 2015 study (year 2), maximum temperatures for the three phases averaged 36.6, 34.4, and $34.4{ }^{\circ} \mathrm{C}$, respectively, whereas minimum temperatures averaged 23.8, 26.6, and 26.1, respectively. Relative humidity during the three 2014 experimental phases averaged $85 \%, 87 \%$, and $87 \%$, respectively. For the 2015 study, relative humidity for the three experimental phases averaged 87\%, 79\%, and $78 \%$, respectively.

Salinity effects on turfgrass quality. Analysis of variance revealed significant cultivar effects on turf quality at all salinity levels, but no cultivar $\times$ year interactions (Table 2 ). In general, turf quality, as noted by $\%$ change between pre- and post-salinity stress, declined in all cultivars as salinity concentration was increased (Table 3). When moving from control to $15-\mathrm{dS} \cdot \mathrm{m}^{-1}$ salinity conditions, 'Celebration' showed a trend toward increased turf quality after 10 weeks of salinity exposure. The majority of other bermudagrass cultivars showed a trend toward decreased turf quality after 6 weeks of exposure to $15-\mathrm{dS} \cdot \mathrm{m}^{-1}$ salinity. Although it showed a slight decrease in quality from control to 15 $\mathrm{dS} \cdot \mathrm{m}^{-1}$, 'SeaStar' exhibited the greatest overall turf quality at $15 \mathrm{dS} \cdot \mathrm{m}^{-1}$, outperforming all cultivars except 'Sea Isle 1' and 'Celebration' with a 7.1 turf quality rating. 'Celebration', 'Sea Isle 1', and 'SeaStar' were the

only cultivars maintaining acceptable $(\geq 6)$ turf quality at $15 \mathrm{dS} \cdot \mathrm{m}^{-1}$.

At $30-\mathrm{dS} \cdot \mathrm{m}^{-1}$ salinity levels, 'Celebration', 'Sea Isle 1', and 'SeaStar' were the only cultivars to maintain acceptable turf quality $(6.6,6.1$, and 6.2 respectively), although they were not statistically different from 'Palisades' and 'Empire' (4.8 and 4.1, respectively). All other cultivars failed to maintain acceptable turf quality at $30 \mathrm{dS} \cdot \mathrm{m}^{-1}$ (Table 3). At $45-\mathrm{dS} \cdot \mathrm{m}^{-1}$ salinity stress, no cultivars maintained acceptable quality. Although 'Sea Isle 1', 'Celebration', and 'SeaStar' showed a trend toward the greatest turf quality at $45 \mathrm{dS} \cdot \mathrm{m}^{-1}$ (turf quality, 1.8, 1.5, and 1.3 , respectively), they did not differ statistically from other cultivars.

Analysis of variance also indicated a significant year main effect on turf quality

Table 2. Analysis of variance for parameters measured at the conclusion of the salinity stress period (postsalinity) and freshwater recovery period (postrecovery) for the control (2.5-), 15-, 30-, and 45$\mathrm{dS} \cdot \mathrm{m}^{-1}$ salinity levels for the Texas A\&M salinity experiments.

\begin{tabular}{|c|c|c|c|c|c|c|c|c|}
\hline & \multicolumn{4}{|c|}{ Postsalinity $^{z}$} & \multicolumn{4}{|c|}{ Postrecovery ${ }^{\mathrm{y}}$} \\
\hline & $\begin{array}{c}\text { Turfgrass } \\
\text { quality }\end{array}$ & NDVI & $\begin{array}{c}\text { Canopy } \\
\text { firing }\end{array}$ & $\begin{array}{c}\text { Shoot } \\
\text { biomass } \\
\text { reduction }\end{array}$ & $\begin{array}{c}\text { Turfgrass } \\
\text { quality }\end{array}$ & NDVI & $\begin{array}{c}\text { Canopy } \\
\text { firing }\end{array}$ & $\begin{array}{c}\text { Root } \\
\text { biomass }\end{array}$ \\
\hline \multicolumn{9}{|c|}{ Control $\left(2.5 \mathrm{dS} \cdot \mathrm{m}^{-1}\right)$} \\
\hline Cultivar & $* *$ & $* * *$ & $* * *$ & & $* * *$ & $* * *$ & $* * *$ & $* * *$ \\
\hline Year & $* * *$ & NS & $* * *$ & & $* *$ & NS & NS & NS \\
\hline Cultivar $\times$ year & NS & NS & NS & & $*$ & NS & $*$ & NS \\
\hline \multicolumn{9}{|l|}{$15 \mathrm{dS} \cdot \mathrm{m}^{-1}$} \\
\hline Cultivar & $* * *$ & $* * *$ & $* * *$ & $*$ & $* * *$ & NS & $* * *$ & $* * *$ \\
\hline Year & $* *$ & $* *$ & $* *$ & $* * *$ & $* *$ & NS & $* * *$ & $* *$ \\
\hline Cultivar $\times$ year & NS & NS & NS & $* *$ & $* *$ & NS & $* * *$ & $* *$ \\
\hline \multicolumn{9}{|l|}{$30 \mathrm{dS} \cdot \mathrm{m}^{-1}$} \\
\hline Cultivar & $* *$ & $* * *$ & $* *$ & NS & $* * *$ & $*$ & $* *$ & $* * *$ \\
\hline Year & NS & $*$ & NS & NS & $* *$ & $*$ & NS & NS \\
\hline Cultivar $\times$ year & NS & NS & NS & NS & NS & NS & NS & NS \\
\hline $45 \mathrm{dS} \cdot \mathrm{m}^{-1}$ & & & & & & & & \\
\hline Cultivar & $* * *$ & $* * *$ & $* * *$ & $* * *$ & $* * *$ & $* * *$ & $* * *$ & $* * *$ \\
\hline Year & $* * *$ & $*$ & $* * *$ & $* * *$ & NS & NS & NS & NS \\
\hline Cultivar $\times$ year & NS & NS & $* * *$ & $* *$ & NS & NS & $* *$ & NS \\
\hline
\end{tabular}

${ }^{\mathrm{z}}$ The salinity stress period was weeks 6 to 10 .

${ }^{\mathrm{y}}$ The recovery period was weeks 11 to 14

NDVI $=$ normalized difference vegetation index.

NS, *,**,**Nonsignificant or significant at $P \leq 0.05,0.01$, or 0.001 , respectively.

Table 3. Main effect of cultivar on turfgrass quality after the salinity stress exposure period (postsalinity) of the Texas A\&M salinity experiments. There was no cultivar $\times$ year interaction at any salinity level; therefore, data are pooled across years.

\begin{tabular}{|c|c|c|c|c|c|c|c|c|c|}
\hline \multirow[b]{3}{*}{ Cultivar } & \multicolumn{9}{|c|}{ Turfgrass quality ${ }^{z}$} \\
\hline & \multicolumn{3}{|c|}{ Control $\left(2.5 \mathrm{dS} \cdot \mathrm{m}^{-1}\right)$} & \multicolumn{2}{|c|}{$15 \mathrm{dS} \cdot \mathrm{m}^{-1}$} & \multicolumn{2}{|c|}{$30 \mathrm{dS} \cdot \mathrm{m}^{-1}$} & \multicolumn{2}{|c|}{$45 \mathrm{dS} \cdot \mathrm{m}^{-1}$} \\
\hline & $\operatorname{Pre}^{y}$ & Post $^{x}$ & $\begin{array}{c}\text { Change } \\
(\%)\end{array}$ & Post $^{x}$ & $\begin{array}{c}\text { Change } \\
(\%)\end{array}$ & Post $^{x}$ & Change \% & Post $^{x}$ & $\begin{array}{c}\text { Change } \\
(\%)\end{array}$ \\
\hline Tifway & 6.8 & 5.8 & -15 & 2.5 & -63 & 2.7 & -60 & 0.5 & -93 \\
\hline Celebration & 6.1 & 8.8 & 44 & 6.9 & 13 & 6.6 & 8 & 1.5 & -75 \\
\hline Empire & 6.3 & 7.6 & 21 & 4.4 & -30 & 4.1 & -35 & 1.3 & -79 \\
\hline Zeon & 6.8 & 4.9 & -28 & 4.1 & -40 & 1.6 & -76 & 0.5 & -93 \\
\hline Palisades & 6.8 & 8.5 & 25 & 4.8 & -29 & 4.8 & -29 & 1.0 & -85 \\
\hline Raleigh & 6.1 & 4.4 & -28 & 2.8 & -54 & 1.6 & -74 & 0.3 & -95 \\
\hline Floratam & 6.9 & 7.3 & 6 & 2.4 & -65 & 2.7 & -61 & 0.5 & -93 \\
\hline Palmetto & 6.2 & 4.1 & -34 & 1.6 & -74 & 2.1 & -66 & 0.5 & -92 \\
\hline Sea Isle 1 & 8.0 & 8.8 & 10 & 6.4 & -20 & 6.1 & -24 & 1.8 & -78 \\
\hline SeaStar & 7.5 & 8.8 & 17 & 7.1 & -5 & 6.2 & -17 & 1.3 & -83 \\
\hline LSD $(0.05)$ & 1.3 & 2.4 & 36 & 2.5 & 39 & 3.1 & 53 & 1.3 & 20 \\
\hline
\end{tabular}

${ }^{\mathrm{z}}$ Turfgrass quality was measured on a 0 - to 9 -point scale, with ratings $\geq 6$ denoting acceptable quality. Positive values denote an increase in quality; negative values denote a decline in quality relative to control.

${ }^{\mathrm{y}}$ The mean turf quality for a given cultivar at the start of week 1 , before salinity exposure.

${ }^{\mathrm{x}}$ The mean turf quality for a given cultivar after week 10 , after the salinity stress period. LSD $=$ least significant difference. 
(Table 2). As such, mean turf quality, when pooling across cultivars and salinity levels, was significantly reduced from year $1(5.2)$ to year 2 (3.7) studies (data not shown). We speculate this may have been related to the higher temperatures and lower relative humidity occurring in year 2 , as daily high and low temperatures were $\approx 2$ and $4{ }^{\circ} \mathrm{C}$ greater in year 2 compared with year 1 (Table 1).

Salinity effects on NDVI. Significant cultivar and year main effects occurred for the final NDVI at all salinity levels; however, there were no significant cultivar $\times$ year interactions at any salinity level, so data were pooled across years of the study (Table 2). A trend toward lower a NDVI was observed as salinity concentration increased with all cultivars (Table 4). 'Celebration' (0.68-0.55), 'Sea Isle 1' (0.73-0.55), and 'SeaStar' (0.74$0.56)$ showed a trend toward the greatest NDVI values when taking into account all cultivars and salinity levels.

Salinity effects on canopy firing. Analysis of variance revealed significant cultivar main effects on canopy firing at all salinity levels; however, there was a cultivar $\times$ year interac-

Table 4. Main effect of cultivar on the normalized difference vegetation index after the salinity stress exposure period (postsalinity) for the Texas A\&M salinity experiments. There was no cultivar $\times$ year interaction detected at any salinity level; therefore, data are pooled across years.

\begin{tabular}{lcccc}
\hline & \multicolumn{4}{c}{ Normalized difference vegetation index } \\
\cline { 2 - 5 } Cultivar & $\begin{array}{c}\text { Control } \\
\left(2.5 \mathrm{dS} \cdot \mathrm{m}^{-1}\right)\end{array}$ & $15 \mathrm{dS} \cdot \mathrm{m}^{-1}$ & $30 \mathrm{dS} \cdot \mathrm{m}^{-1}$ & $45 \mathrm{dS} \cdot \mathrm{m}^{-1}$ \\
\hline Tifway & 0.64 & 0.62 & 0.52 & 0.47 \\
Celebration & 0.68 & 0.68 & 0.63 & 0.55 \\
Empire & 0.68 & 0.61 & 0.55 & 0.48 \\
Zeon & 0.58 & 0.54 & 0.50 & 0.38 \\
Palisades & 0.71 & 0.60 & 0.62 & 0.48 \\
Raleigh & 0.46 & 0.42 & 0.42 & 0.34 \\
Floratam & 0.55 & 0.50 & 0.46 & 0.37 \\
Palmetto & 0.43 & 0.40 & 0.51 & 0.35 \\
Sea Isle & 0.73 & 0.67 & 0.63 & 0.55 \\
SeaStar & 0.74 & 0.71 & 0.66 & 0.56 \\
LSD (0.05) & 0.10 & 0.10 & 0.16 & 0.14 \\
\hline
\end{tabular}

${ }^{\mathrm{z}}$ The normalized difference vegetation index was measured using a Spectrum Field Scout TCM 500 NDVI Turf Color Meter.

LSD $=$ least significant difference. tion that was significant at the $45-\mathrm{dS} \cdot \mathrm{m}^{-1}$ salinity level (Table 2). Percent change in canopy firing between pre- and postsalinity stress increased with increasing salinity concentration in all cultivars. 'SeaStar', 'Celebration', and 'Sea Isle 1' sustained the lowest amounts of canopy firing $(7.6,7.5$, and 6.8 , respectively) at $15 \mathrm{dS} \cdot \mathrm{m}^{-1}$ (Table 5). Also, a trend toward decreased firing was noted in 'Celebration' when moving from 2.5- to 15$\mathrm{dS} \cdot \mathrm{m}^{-1}$ salinity (7.0 vs. 7.5 , respectively). St. augustinegrass and zoysiagrass cultivars, as well as 'Tifway', all showed substantial canopy firing $(3.6-5.1)$ at the $15-\mathrm{dS} \cdot \mathrm{m}^{-1}$ salinity level. At $30-\mathrm{dS} \cdot \mathrm{m}^{-1}$ salinity, 'Celebration' and 'Sea Isle 1' maintained the lowest levels of leaf firing (6.0) of all cultivars; however, they were not statistically different from any other cultivars except 'Raleigh', 'Floratam', and 'Zeon'. At 45 -dS.m ${ }^{-1}$, there was a cultivar $x$ year interaction, so data were split by year (Table 5). Canopy firing ranged from 5.2 to 0 in year 1, with 'Celebration' outperforming all other cultivars except 'SeaStar' and 'Tifway'. In year 2, canopy firing ranged from 1.7 to 0.5 . In general, canopy firing was less pronounced in year $1(2.2)$ compared to year $2(0.8)$ at $45 \mathrm{dS} \cdot \mathrm{m}^{-1}$.

Shoot biomass reduction. Analysis of variance detected significant cultivar $\times$ year interactions at both the $15-$ and $45-\mathrm{dS} \cdot \mathrm{m}^{-1}$ salinity levels (Table 2). In general, biomass reductions occurred with increasing salinity level across all cultivars, and reductions were considerably more severe in year 2 than year 1 (Table 6). The most vigorously growing turfgrass under mild and moderate levels of salinity in year 1 was 'Sea Isle 1', which actually increased biomass production $(97 \%$, and $23 \%$ increased growth) relative to controls at both the 15 - and 30 $\mathrm{dS} \cdot \mathrm{m}^{-1}$ salinity levels. Despite previously noted differences in turf quality and firing, 'Tifway', 'Empire', 'Palisades', 'Floratam', and 'Palmetto' all showed increased growth at the $15-\mathrm{dS} \cdot \mathrm{m}^{-1}$ salinity level in year 1 ; however, all exhibited reduced growth at this same EC level during year 2. Less severe biomass reductions under salinity stress occurred in year 1, during which time cooler average temperatures of 26.6 and $28.3^{\circ} \mathrm{C}$ for the acclimation and salinity stress periods, respectively, were recorded than for year 2 (Table 2). At $45-\mathrm{dS} \cdot \mathrm{m}^{-1}$ salinity, st. augustinegrass cultivars generally experienced the most severe biomass reductions $(86.5 \%$ to $100 \%$ reductions in year $1,80.3 \%$ to $90.4 \%$ reductions in year 2 ); however, these were not significantly different from some other cultivars (Table 6). By comparison, bermudagrass and seashore paspalum cultivars exhibited a trend toward the least reductions in shoot biomass $(\approx 49 \%$ to $69 \%$ reductions) during year 1 . In year 2 , seashore paspalum cultivars again sustained somewhat less biomass reduction than other species at $45 \mathrm{dS} \cdot \mathrm{m}^{-1}$; however, differences were not significant.

Postrecovery turfgrass quality. In general, there were significant cultivar and year main effects for postrecovery turfgrass quality at all salinity levels; however, there was a significant cultivar $\times$ year interaction at 15

Table 5. Main effect of cultivar on canopy firing after the salinity stress exposure period (postsalinity) during the Texas A\&M salinity experiment. Within the control, $15-$, or $30-\mathrm{dS} \cdot \mathrm{m}^{-1}$ treatments, there were no cultivar $\times$ year interactions detected; therefore, data are pooled across years. Percent change was determined by comparing the 'post' (end of week 10) to 'pre' (before salinity stress) canopy firing for each entry. Positive \% change values denote reduced leaf firing, while negative $\%$ change values denote increased canopy firing due to salinity stress.

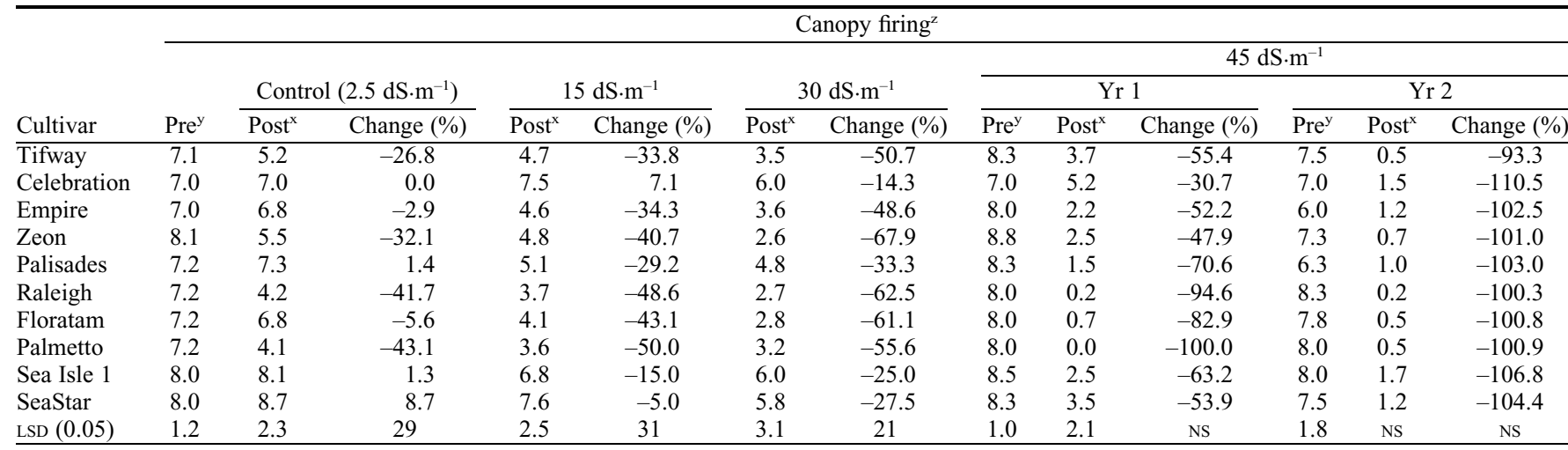

${ }^{\mathrm{z}}$ Canopy firing was evaluated using a 0 - to 9 -point scale, where $0=$ no green tissue in the canopy and $9=$ completely green canopy with no brown tissue present ${ }^{\mathrm{y}}$ Canopy leaf firing at the start of the acclimation period, before salinity stress is imposed.

${ }^{\mathrm{x}}$ Canopy leaf firing at the conclusion of the salinity stress period (week 10).

LSD $=$ least significant difference; $\mathrm{NS}=$ nonsignificant. 
Table 6. Shoot biomass change (relative to $2.5 \mathrm{dS} \cdot \mathrm{m}^{-1}$ control) at $15-, 30-$, and $45-\mathrm{dS} \cdot \mathrm{m}^{-1}$ salinity levels for the Texas A\&M salinity experiments. Cultivar $\times$ year interaction was significant at the $15-$ and $45-$ $\mathrm{dS} \cdot \mathrm{m}^{-1}$ salinity levels; therefore, data are split by year.

\begin{tabular}{|c|c|c|c|c|c|c|}
\hline \multirow[b]{3}{*}{ Cultivar } & \multicolumn{6}{|c|}{ Shoot biomass reduction ${ }^{\mathrm{z}}(\%)$} \\
\hline & \multicolumn{2}{|c|}{$15 \mathrm{dS} \cdot \mathrm{m}^{-1}$} & \multicolumn{2}{|c|}{$30 \mathrm{dS} \cdot \mathrm{m}^{-1}$} & \multicolumn{2}{|c|}{$45 \mathrm{dS} \cdot \mathrm{m}^{-1}$} \\
\hline & Yr 1 & Yr 2 & Yr 1 & Yr 2 & Yr 1 & Yr 2 \\
\hline Tifway & 49.4 & -22.4 & -41.2 & -42.3 & -52.6 & -82 . \\
\hline Celebration & -2.0 & -48.0 & -52.1 & -44.0 & -72.4 & -86 \\
\hline Empire & 22.8 & -66.0 & -12.5 & -60.1 & -55.7 & -87 . \\
\hline Zeon & -23.8 & -34.4 & -39.0 & -33.7 & -61.8 & -100 \\
\hline Palisades & 35.0 & -57.1 & -12.1 & -58.3 & -74.0 & -86 \\
\hline Raleigh & -16.5 & -35.7 & -46.1 & -41.9 & -98.0 & -80 . \\
\hline Floratam & 41.1 & -74.0 & -43.5 & -76.6 & -86.5 & -93 \\
\hline Palmetto & 6.0 & -39.2 & -21.4 & -40.2 & -100.0 & -90 \\
\hline Sea Isle 1 & 97.0 & -29.9 & 23.0 & -32.3 & -49.0 & -74 \\
\hline SeaStar & -7.5 & -8.4 & -47.8 & -13.5 & -69.3 & -62 \\
\hline LSD $(0.05)$ & 68.0 & NS & NS & NS & 33.6 & 25 \\
\hline
\end{tabular}

${ }^{\mathrm{z}}$ Shoot biomass reduction $=[1-(a / b)] \times 100$, where $a$ is the clipping dry weight average over a 5-week salinity stress exposure period for a given cultivar and replicate within a given salinity treatment, and $b$ is the clipping dry weight average over a 5-week salinity stress exposure period for the same cultivar and replicate within the control treatment. Positive values denote increased shoot biomass; negative values denote decreased shoot biomass relative to the control.

LSD = least significant difference; NS = nonsignificant.

Table 7. Postrecovery turfgrass quality of cultivars after the 4-week freshwater recovery period at four salinity levels for the Texas A\&M salinity experiments. Ratings of $\geq 6$ denote acceptable turf quality. Cultivar $\times$ year interaction was significant for the control and $15 \mathrm{dS} \cdot \mathrm{m}^{-1}$ treatments; therefore, data have been split by year.

\begin{tabular}{lccccc}
\hline & \multicolumn{5}{c}{ Turfgrass Quality $^{z}$} \\
\cline { 2 - 6 } Cultivar & Control $\left(2.5 \mathrm{dS} \cdot \mathrm{m}^{-1}\right)$ & Yr 1 & Yr 2 & $30 \mathrm{dS} \cdot \mathrm{m}^{-1} \mathrm{~m}^{-1}$ & $45 \mathrm{dS} \cdot \mathrm{m}^{-1}$ \\
\cline { 2 - 5 } Tifway & 4.3 & 6.3 & 1.5 & 2.3 & 2.3 \\
Celebration & 4.9 & 7.0 & 5.8 & 4.6 & 3.9 \\
Empire & 5.1 & 4.5 & 5.0 & 3.1 & 2.9 \\
Zeon & 4.9 & 3.8 & 4.8 & 3.1 & 2.0 \\
Palisades & 5.3 & 4.8 & 5.3 & 4.0 & 0.9 \\
Raleigh & 2.4 & 2.5 & 2.8 & 2.4 & 0.8 \\
Floratam & 3.5 & 3.5 & 3.8 & 3.4 & 0.6 \\
Palmetto & 2.6 & 2.5 & 1.0 & 2.0 & 2.6 \\
Sea Isle 1 & 6.1 & 7.3 & 5.5 & 5.5 & 3.8 \\
SeaStar & 6.3 & 7.8 & 6.3 & 5.6 & 1.7 \\
LSD $(0.05)$ & 2.4 & 2.4 & 2.8 & 2.8 & \\
\hline Thyyyyy
\end{tabular}

${ }^{\mathrm{z}}$ Turfgrass quality was measured on a 0 - to 9-point scale, with ratings $\geq 6$ denoting acceptable quality. LSD $=$ least significant difference.

Table 8. Postrecovery normalized difference vegetation index of cultivars after the 4-week freshwater recovery period at four salinity levels for the Texas A\&M salinity experiments. There were no cultivar $\times$ year interactions at any salinity level, so data are pooled across year.

\begin{tabular}{lcccc}
\hline & \multicolumn{4}{c}{ Normalized difference vegetation index $^{z}$} \\
\cline { 2 - 5 } Cultivar & Control $\left(2.5 \mathrm{dS} \cdot \mathrm{m}^{-1}\right)$ & $15 \mathrm{dS} \cdot \mathrm{m}^{-1}$ & $30 \mathrm{dS} \cdot \mathrm{m}^{-1}$ & $45 \mathrm{dS} \cdot \mathrm{m}^{-1}$ \\
\hline Tifway & 0.564 & 0.589 & 0.580 & 0.550 \\
Celebration & 0.586 & 0.660 & 0.650 & 0.586 \\
Empire & 0.629 & 0.625 & 0.631 & 0.584 \\
Zeon & 0.568 & 0.559 & 0.576 & 0.457 \\
Palisades & 0.623 & 0.649 & 0.606 & 0.559 \\
Raleigh & 0.359 & 0.388 & 0.504 & 0.397 \\
Floratam & 0.453 & 0.464 & 0.536 & 0.352 \\
Palmetto & 0.316 & 0.365 & 0.381 & 0.321 \\
Sea Isle 1 & 0.649 & 0.650 & 0.640 & 0.602 \\
SeaStar & 0.612 & 0.670 & 0.636 & 0.625 \\
LSD (0.05) & 0.123 & $\mathrm{NS}$ & 0.124 & 0.158 \\
\hline
\end{tabular}

${ }^{\mathrm{z}}$ Normalized difference vegetation index was measured using a Spectrum Field Scout TCM 500 NDVI Turf Color Meter.

LSD $=$ least significant difference.

$\mathrm{dS} \cdot \mathrm{m}^{-1}$ (Table 2). Within the control treatment, all but seashore paspalum cultivars showed below-acceptable turf quality after 4 weeks of freshwater recovery (Tables 2 and 7). The lowest quality within the controls occurred within st. augustinegrass cultivars, the only cultivar with acceptable quality after recovery from $15-\mathrm{dS} \cdot \mathrm{m}^{-1}$ salinity. No cultivars showed acceptable turf quality after 4 weeks of recovery from 30 and $45 \mathrm{dS} \cdot \mathrm{m}^{-1}$; however, 'SeaStar' (5.6 and 3.8), 'Sea Isle 1' (5.5 and 2.6), and 'Celebration' (4.6 and 3.9) showed a trend toward greater overall turf quality (Table 7).

Postrecovery NDVI. Cultivar main effects occurred for postrecovery NDVI at all salinity levels except $15 \mathrm{dS} \cdot \mathrm{m}^{-1}$ (Table 2 ). When considering all cultivars and salinity levels, 'Sea Isle 1' (0.649-0.602) and 'SeaStar' (0.612-0.625) showed a trend toward the greatest NDVI after the freshwater recovery period (Table 8). Across salinity levels, zoysiagrass cultivars Empire and Palisades generally exhibited the next greatest postrecovery NDVI ratings, superior to that of 'Zeon' zoysiagrass. At all salinity levels, NDVI was the least in the st. augustinegrass cultivars (0.316-0.504), although not statistically less than some other cultivars.

Postrecovery canopy firing. Analysis of variance detected significant cultivar main effects for postrecovery canopy firing at all salinity levels, as well as cultivar $\times$ year interactions at $2.5-, 15-$, and $45-\mathrm{dS} \cdot \mathrm{m}^{-1}$ salinity levels (Table 2). 'Sea Isle 1' (7.3 to 3.5 ) and 'SeaStar' (7.0 to 5.3) showed a trend of the least postrecovery turf firing among all cultivars (Table 9). 'Celebration' (7.5 and 4.0) also showed a trend toward the strongest recovery, with similarly low levels of canopy firing after the freshwater recovery period at both 15 to $45 \mathrm{dS} \cdot \mathrm{m}^{-1}$ (Table 9).

Salinity effects on root biomass. Analysis of variance showed a significant cultivar $x$ year interaction for final root dry weight at the $15-\mathrm{dS} \cdot \mathrm{m}^{-1}$ salinity level, as well as significant cultivar main effects for final root dry weight at all salinity levels (Table 2). Therefore, root data were pooled between years for the 30- and 45-dS. $\mathrm{m}^{-1}$ salinity levels (Table 10). Significant differences occurred among the 10 cultivars for root dry weight under both control $\left(2.5 \mathrm{dS} \cdot \mathrm{m}^{-1}\right)$ and $15-\mathrm{dS} \cdot \mathrm{m}^{-1}$ salinity levels, with seashore paspalum cultivars producing a greater amount of root biomass than many of the other species. 'Palmetto' and 'Zeon'- two of the least salinity-tolerant cultivars based on turf quality, firing, and NDVI ratings - showed a trend toward increased root biomass relative to other cultivars $(170 \%$ and $124 \%$, respectively) at the $15-\mathrm{dS} \cdot \mathrm{m}^{-1}$ salinity level in year 1. In year 2 , seashore paspalum cultivars ('Sea Isle 1' and 'SeaStar') exhibited a trend toward greater root growth than other cultivars (2.3 and $2.5 \mathrm{~g}$ dry weight, respectively), and 'Raleigh' increased root growth $113 \%$ at $15 \mathrm{dS} \cdot \mathrm{m}^{-1}$ relative to controls.

At $30 \mathrm{dS} \cdot \mathrm{m}^{-1}$, 'Sea Isle 1' and 'SeaStar' had greater root dry weights $(2.5$ and $2.8 \mathrm{~g}$, respectively) than a number of other cultivars; however, no significant differences were detected among cultivars for percent biomass reduction. Although not statistically significant, 'Palisades' and 'Palmetto' showed a trend toward the greatest increases (60\% and 52\% increases), whereas 'Empire' 
and 'Celebration' (21\% and 14\% decreases) expressed a trend toward the greatest decreases in root growth (Table 10).

At the $45-\mathrm{dS} \cdot \mathrm{m}^{-1}$ salinity level, no significant differences in root dry weight were detected among cultivars, but a trend toward increased root growth was again found in 'Sea Isle 1' and 'SeaStar' (2.3 and $2.1 \mathrm{~g}$, respectively), with the least root growth observed in 'Zeon' and 'Raleigh' (0.5 and $0.7 \mathrm{~g}$, respectively). With the exception of 'Palmetto' and 'Palisades', which showed $20 \%$ and $4 \%$ increases in root growth, respectively, all entries at $45 \mathrm{dS} \cdot \mathrm{m}^{-1}$ suffered reduced root growth relative to controls.

\section{Discussion}

Previous research has shown both interand intraspecific differences exist with regard to salinity tolerance in turfgrasses. For example, Marcum et al. (1998) reported that Zoysia matrella cultivars exhibited improved turf quality compared with Zoysia japonica cultivars under increasing salinity. In our study, seashore paspalum and bermudagrass cultivars generally outperformed both zoysiagrass and st. augustinegrass cultivars at higher salinity levels, and Z. japonica cultivars Palisades and Empire generally exhibited improved salinity tolerance compared with Z. matrella cultivar Zeon. Within the bermudagrasses, 'Celebration' exhibited superior turf quality to 'Tifway' under elevated salinity, maintaining acceptable levels of quality relative to other cultivars under both $15-$ and $30-\mathrm{dS} \cdot \mathrm{m}^{-1}$ salinity. Seashore paspalum cultivars generally exhibited superior salinity tolerance to other cultivars, showing the greatest turf quality at 15$\mathrm{dS} \cdot \mathrm{m}^{-1}$ salinity and also maintaining minimally acceptable quality at $30 \mathrm{dS} \cdot \mathrm{m}^{-1}$.

The majority of cultivars in this study fell to below acceptable turf quality at 15 $\mathrm{dS} \cdot \mathrm{m}^{-1}$ salinity concentrations (Table 3 ). Based on our collective results, the relative salinity tolerance observed at the $15-\mathrm{dS} \cdot \mathrm{m}^{-1}$ salinity concentration occurred in the following order, from highest to lowest observed tolerance: seashore paspalum $>$ bermudagrass species $>$ zoysiagrass species $>$ st. augustinegrass. These rankings differ to some extent from those reported by Marcum and Murdoch (1994), who found seashore

Table 9. Postrecovery canopy firing of cultivars after the freshwater recovery period at four salinity levels for the Texas A\&M salinity experiments. A year $\times$ cultivar interaction was not significant for the control or the $30-\mathrm{dS} \cdot \mathrm{m}^{-1}$ salinity level; therefore, data are pooled by year.

\begin{tabular}{|c|c|c|c|c|c|c|}
\hline \multirow[b]{2}{*}{ Cultivar } & \multirow[b]{2}{*}{ Control $\left(2.5 \mathrm{dS} \cdot \mathrm{m}^{-1}\right)$} & \multicolumn{2}{|c|}{$15 \mathrm{dS} \cdot \mathrm{m}^{-1}$} & \multirow[b]{2}{*}{$30 \mathrm{dS} \cdot \mathrm{m}^{-1}$} & \multicolumn{2}{|c|}{$45 \mathrm{dS} \cdot \mathrm{m}^{-1}$} \\
\hline & & Yr 1 & Yr 2 & & Yr 1 & Yr 2 \\
\hline Tifway & 4.6 & 6.5 & 1.8 & 2.6 & 2.8 & 2.5 \\
\hline Celebration & 5.5 & 7.5 & 6.3 & 5.3 & 4.0 & 5.0 \\
\hline Empire & 6.1 & 4.5 & 7.3 & 3.9 & 1.8 & 5.8 \\
\hline Zeon & 4.9 & 3.3 & 6.3 & 3.8 & 1.8 & 3.8 \\
\hline Palisades & 6.4 & 4.3 & 7.3 & 4.5 & 1.0 & 6.0 \\
\hline Raleigh & 2.8 & 2.3 & 3.8 & 3.2 & 0.5 & 0.3 \\
\hline Floratam & 4.6 & 4.3 & 5.3 & 3.9 & 0.5 & 0.8 \\
\hline Palmetto & 2.8 & 3.3 & 1.5 & 2.4 & 0.3 & 0.0 \\
\hline Sea Isle 1 & 7.3 & 7.5 & 7.0 & 6.1 & 3.0 & 3.5 \\
\hline SeaStar & 7.0 & 7.5 & 7.3 & 6.1 & 3.8 & 5.3 \\
\hline $\operatorname{LSD}(0.05)$ & 2.5 & 2.6 & 2.9 & 3.0 & 2.7 & 3.6 \\
\hline
\end{tabular}

Canopy firing was rated visually using a 0 - to 9 -point scale, where $0=$ no green tissue in the canopy and $9=$ completely green canopy with no brown tissue present.

LSD $=$ least significant difference.

paspalum ('Hawaii selection'), manilagrass ('Matrella'), and st. augustinegrass ('Hawaii selection') all had superior salinity tolerance to 'Tifway' bermudagrass (intermediate tolerance), and 'Korean Common' japanese lawngrass (sensitive). This may suggest that considerable interspecific variability may exist within warm-season cultivars, as st. augustinegrass cultivars (Raleigh, Floratam, and Palmetto) generally underperformed all other species in our study.

Xiang et al. (2017) evaluated salinity tolerance via subirrigation across a set of bermudagrasses including 'Celebration' and 'Tifway', testing across similar salinity levels to ours, from 1.5 to $45 \mathrm{dS} \cdot \mathrm{m}^{-1}$. In contrast to our results, however, the authors reported similar or slightly improved performance of 'Tifway' relative to 'Celebration' at 30- and $45-\mathrm{dS} \cdot \mathrm{m}^{-1}$ EC levels. This discrepancy may be attributable to differences in the water used for the periodic overhead irrigation events. Although we flushed pots periodically using municipal tap water, Xiang et al. (2017) reported doing so using the respective salinity treatment solutions, which would likely have resulted in direct salinity stress to turfgrass shoots. The contrasting results between these two studies suggest that cultivar responses to irrigation salinity may depend on whether irrigation is supplied overhead (shoot and root stress) or via subirrigation (root stress only). As such, although 'Celebration' may offer superior root tolerance to salinity stress, 'Tifway' may have relatively greater shoot tolerance to osmotic stress than 'Celebration'. These findings also highlight the potential importance of irrigation system design (overhead vs. drip) when selecting the appropriate salinity-tolerant cultivars.

The observed shoot growth stimulation at low levels of salinity has also been reported previously in salt-tolerant grasses, including seashore paspalum and st. augustinegrass at salinity less than $15 \mathrm{dS} \cdot \mathrm{m}^{-1}$ (Marcum and Murdoch, 1994). In fact, seashore paspalum ecotypes as well as 'Tifgreen', 'Tifway', and

Table 10 . Final root dry weight and root biomass change relative to controls at the conclusion of the Texas A\&M salinity study. A cultivar $\times$ year interaction was detected at the $15-\mathrm{dS} \cdot \mathrm{m}^{-1}$ salinity level; therefore, data are split by year. Positive values denote increased root biomass relative to the Control, while negative values denote decreased root biomass relative to the Control.

\begin{tabular}{|c|c|c|c|c|c|c|c|c|c|}
\hline \multirow[b]{3}{*}{ Cultivars } & \multirow{3}{*}{$\begin{array}{l}\text { Control root } \\
\text { dry } \mathrm{wt}^{\mathrm{z}}(\mathrm{g})\end{array}$} & \multicolumn{4}{|c|}{$15 \mathrm{dS} \cdot \mathrm{m}^{-1}$} & \multicolumn{2}{|c|}{$30 \mathrm{dS} \cdot \mathrm{m}^{-1}$} & \multicolumn{2}{|c|}{$45 \mathrm{dS} \cdot \mathrm{m}^{-1}$} \\
\hline & & $\begin{array}{l}\text { Root dry } \\
w^{z}(g)\end{array}$ & $\begin{array}{l}\text { Root biomass } \\
\text { change }^{\mathrm{y}}(\%)\end{array}$ & $\begin{array}{l}\text { Root dry } \\
w^{z}(g)\end{array}$ & $\begin{array}{l}\text { Root biomass } \\
\text { change }^{\mathrm{y}}(\%)\end{array}$ & \multirow{2}{*}{$\begin{array}{l}\text { Root dry } \\
w^{z}(g)\end{array}$} & \multirow{2}{*}{$\begin{array}{c}\text { Root biomass } \\
\text { change }^{\mathrm{y}}(\%)\end{array}$} & \multirow{2}{*}{$\begin{array}{l}\text { Root dry } \\
w^{\mathrm{z}}(\mathrm{g})\end{array}$} & \multirow{2}{*}{$\begin{array}{l}\text { Root biomass } \\
\text { change }^{\mathrm{y}}(\%)\end{array}$} \\
\hline & & \multicolumn{2}{|c|}{ Yr 1} & \multicolumn{2}{|c|}{ Yr 2} & & & & \\
\hline Tifway & 1.1 & 2.4 & 46 & 0.8 & 59 & 1.3 & 23 & 0.9 & -8 \\
\hline Celebration & 1.8 & 2.5 & 45 & 2.5 & 29 & 1.5 & -14 & 1.3 & -26 \\
\hline Empire & 1.3 & 1.1 & 5 & 1.5 & -8 & 1.0 & -21 & 1.0 & -23 \\
\hline Zeon & 0.9 & 1.2 & 124 & 0.8 & -32 & 0.8 & 10 & 0.5 & -24 \\
\hline Palisades & 1.1 & 0.9 & -33 & 1.1 & 27 & 1.6 & 60 & 1.1 & 4 \\
\hline Raleigh & 1.3 & 1.5 & -6 & 2.0 & 113 & 1.3 & 9 & 0.7 & -42 \\
\hline Floratam & 1.9 & 1.5 & -5 & 1.6 & -30 & 2.1 & 12 & 1.1 & -38 \\
\hline Palmetto & 1.2 & 2.9 & 170 & 0.6 & -52 & 1.7 & 52 & 1.4 & 20 \\
\hline Sea Isle 1 & 2.6 & 3.7 & 24 & 2.3 & 1 & 2.5 & -6 & 2.3 & -12 \\
\hline SeaStar & 2.5 & 3.2 & 8 & 2.5 & 24 & 2.8 & 17 & 2.1 & -14 \\
\hline LSD $(0.05)$ & 1.1 & 1.5 & 139 & 1.4 & 136 & 1.3 & NS & 1.0 & NS \\
\hline
\end{tabular}

${ }^{\mathrm{z}}$ Root dry weights were obtained at the end of the freshwater recovery period (week 14).

${ }^{\mathrm{y}}$ Root biomass change $=[1-(a / b)] \times 100$, where $a$ is the final root dry weight for a given cultivar and replicate within a given salinity treatment and $b$ is the final root dry weight for the same cultivar and replicate in the control treatment.

LSD $=$ least significant difference; $\mathrm{NS}=$ nonsignificant. 
'TifEagle' bermudagrass have all reportedly shown shoot growth stimulation at $24 \mathrm{dS} \cdot \mathrm{m}^{-1}$ relative to control levels of salinity (Greenway and Munns, 1980; Lee et al., 2004). Although not likely a substantial source of nutrient addition, the Instant Ocean salt used to create salinity treatments in our study contains trace amounts of micronutrients (Atkinson and Bingman, 1997), which could have aided in shoot growth responses at $15-\mathrm{dS} \cdot \mathrm{m}^{-1}$ salinity. This may also help to explain the somewhat low levels of quality observed in control plants later in study, given that these plants had not received Instant Ocean for the prior 10-week study. In our study, shoot growth reductions differed by year, but greater overall biomass reductions for most cultivars occurred in year 2. We speculate that higher temperatures during year 2 may have compounded salinity stress effects. 'Empire', 'Palisades', and 'Floratam' all experienced the greatest biomass reduction declines from year 1 to year 2 , possibly indicating relatively greater sensitivity within these cultivars to combined salinity and heat stress.

Carrow and Duncan (2011) reported that turfgrasses that have inherently vigorous root growth characteristics are often those that are better adapted for growth in or recovery from adverse abiotic stresses such as sodic and saline soils, extreme temperatures, ion toxicities, and nutrient imbalances. Furthermore, root growth stimulation under saline conditions has previously been reported in bermudagrass (Carrow et al., 2001b), seashore paspalum (Lee et al., 2004), and st. augustinegrass (Meyer et al., 1989; Peacock et al., 1993). In our study, root growth appeared to be less affected to salinity treatments than shoot growth. The observation of maintained or even increased root growth by st. augustinegrass cultivars under increasing salinity is interesting, considering the poor performance of the species with regard to turf quality and clipping production at these same levels. Based on our results, a number of the warmseason species and cultivars tested exhibit halophytic attributes based on their increased shoot and root biomass production under low to moderate salinity levels $\left(\leq 15 \mathrm{dS} \cdot \mathrm{m}^{-1}\right)$. Such responses to salinity stress may occur through adaptive mechanisms to prevent ion toxicity, osmotic stress, and/or ion imbalance, resulting in more efficient water and nutrient uptake under salinity (Gorham et al., 1985).

\section{Conclusions}

Turfgrass response to salinity stress is complex. It involves several physiological mechanisms and depends on salinity concentration, length of exposure, and effects of other compounding stresses such as mineral nutrition imbalance, osmotic stress, and stomatal closure. The warm-season turfgrass species and cultivars evaluated in this study demonstrated a wide range of salinity tolerance, and responses varied between studies. The results should also be taken in the context of a subirrigated system with no drought stress that was flushed routinely, and only belowground tissues were exposed to salinity stress. Although it is difficult to assign precise salinity thresholds to each cultivar as a result of variability between studies, relative salinity tolerance ranges of these cultivars, based on maintenance of acceptable turf quality, ranged from $30 \mathrm{dS} \cdot \mathrm{m}^{-1}$ ('Sea Isle 1', 'SeaStar', and 'Celebration'), to between 2.5 and $15 \mathrm{dS} \cdot \mathrm{m}^{-1}$ (all other cultivars). Although not directly corresponding to turf quality responses, based on $50 \%$ clipping biomass reduction thresholds, 'Empire', 'Palisades', and 'Floratam' tolerated less than $15 \mathrm{dS} \cdot \mathrm{m}^{-1}$; 'Celebration' tolerated between 15 and $30 \mathrm{dS} \cdot \mathrm{m}^{-1}$; and all other cultivars tolerated between 30 - and $45-\mathrm{dS} \cdot \mathrm{m}^{-1}$ salinity. Although these levels may exceed those of practical significance in the field, they provide comparative data on the relative salinity tolerance of commonly used warmseason turf cultivars, as well as their ability to recuperate from periodic salt stress injury. The results also suggest that future breeding and physiology studies should examine more closely the interaction of temperature as well as irrigation delivery method on turfgrass salinity tolerance.

\section{Literature Cited}

Abraham, E.M., W.A. Meyer, S.A. Bonos, and B. Huang. 2008. Differential responses of hybrid bluegrass and kentucky bluegrass to drought and heat stress. HortScience 43:2191-2195.

Armstrong, A.S.B., D.W. Rycroft, and T.W. Tanton. 1996. Seasonal movement of salts in naturally structured saline-sodic clay soils. Agr. Water Mgt. 32:15-27.

Atkinson, M.J. and C. Bingman. 1997. Elemental composition of commercial seasalts. J. Aquaricult. Aquat. Sci. 8:39-43.

Carrow, R.N. and R.R. Duncan. 2011. Best management practices for saline and sodic turfgrass soils: Assessment and reclamation. CRC Press, Boca Raton, FL.

Carrow, R., D. Waddington, and P. Rieke. 2001a. Turfgrass soil fertility and chemical problems: Assessment and problems. Ann Arbor Press, Chelsea, MI.

Carrow, R.N., D.V. Waddington, and P.E. Rieke. 2001b. Turfgrass soil fertility \& chemical problems: Assessment and management. Wiley, Hoboken, NJ.

Devitt, D., R. Morris, D. Kopec, and M. Henry. 2004. Golf course superintendents' attitudes and perceptions toward using reuse water for irrigation in the southwestern United States. HortTechnology 14:577-583.

Duble, R.L. 1996. Turfgrasses: Their management and use in the southern zone. 2nd ed. Texas A\&M University Press, College Station, TX.

Golf Course Superintendents Association of America. 2015. Water use and conservation practices on U.S. golf courses. Golf course environmental profile phase II, vol. I. Golf Course Superintendents Association of America, Lawrence, KS.
Gorham, J., R.G. Wyn Jones, and E. McDonnell. 1985. Some mechanisms of salt tolerance in crop plants, p. 15-40. In: D. Pasternak and A. San Pietro (eds.). Biosalinity in action: Bioproduction with saline water. Developments in Plant and Soil Sciences, vol 17. Springer, Dordrecht.

Greenway, H. and R. Munns. 1980. Mechanisms of salt tolerance in nonhalophytes. Annu. Rev. Plant Physiol. 31:149-190.

Hayes, A., C. Mancino, and I. Pepper. 1990 Irrigation of turfgrass with secondary sewage effluent: I. Soil and leachate water quality. Agron. J. 82:939-943.

Harivandi, M.A. 2008. Irrigating sports turf with municipal recycled water. Acta Hort. 783:215220.

Huang, B., M. DaCosta, and Y. Jiang. 2014. Research advances in mechanisms of turfgrass tolerance to abiotic stresses: From physiology to molecular biology. Crit. Rev. Plant Sci. 33:141-189.

Lee, G., R.R. Duncan, and R.N. Carrow. 2004. Salinity tolerance of seashore paspalum ecotypes: Shoot growth responses and criteria. HortScience 39:1138-1142.

Marcum, K.B., S.J. Anderson, and M. Engelke. 1998. Salt gland ion secretion: A salinity tolerance mechanism among five zoysiagrass species. Crop Sci. 38:806-810.

Marcum, K.B. and C.L. Murdoch. 1994. Salinity tolerance mechanisms of six $\mathrm{C} 4$ turfgrasses. J. Amer. Soc. Hort. Sci. 119:779-784.

Meyer, M., M. Smith, and S. Knight. 1989. Salinity effects on St. Augustinegrass: A novel system to quantify stress response 1. J. Plant Nutr. 12:893-908.

Moreaux, M. and A. Reynaud. 2001. Optimal management of a coastal aquifer under saline intrusion. Presented at the First International Conference and Workshop on Saltwater Intrusion and Coastal Aquifers, Monitoring, Modelling, and Management. 23-25 Apr. 2001. Essaouira, Morocco.

Morris, K.N. and R.C. Shearman. 1998. NTEP turfgrass evaluation guidelines: NTEP turfgrass evaluation workshop, p. 1-5. National Turfgrass Evaluation Program, Beltsville, MD.

Peacock, C., A. Dudeck, and J. Wildmon. 1993. Growth and mineral content of St. Augustinegrass cultivars in response to salinity. J. Amer. Soc. Hort. Sci. 118:464-469.

Raymer, P.L., R.N. Carrow, and D.A. Wyatt. 2005 Screening for salt tolerance in seashore paspalum. Proc. Inter. Salinity Forum. 25-27 Apr. 2005. Riverside, CA. p. 129-133.

Rojeski, P., Jr. and S. Luster-Teasley. 2008. The impact of state regulations on innovative wastewater treatment implementation: Trends for on-site wastewater disposal in North Carolina. World Environmental and Water Resources Congress. $<\mathrm{https} / / /$ ascelibrary.org/doi/ abs $/ 10.1061 / 40976 \% 28316 \% 29123>$.

Uddin, M.K. and A.S. Juraimi. 2013. Salinity tolerance turfgrass: History and prospects Scientific World J. 2013:409-413.

U.S. Golf Association. 2004. USGA recommendations for a method of putting green construction. $<$ http://www.usga.org/course-care/digitalcollections/ creating-usga-putting-green.html $>$.

Xiang, M., J.Q. Moss, D.L. Martin, K. Su, and B.L. Dunn. 2017. Evaluating the salinity tolerance of clonal-type bermudagrass cultivars and an experimental Selection. HortScience 52:185191. 